\title{
Budget Education and Management as a Necessity for Well-Being and Financial Stability: Cluster \& MDS Analysis
}

\author{
Enkeleda Lulaj ${ }^{1}$ \\ ${ }^{1}$ University "Haxhi Zeka", Eliot Engel, State of the Kosovo \\ Correspondence: Enkeleda Lulaj (Phd.), University "Haxhi Zeka", 30.000 Peja, Eliot Engel, State of the Kosovo. \\ E-mail: enkeleda.lulaj@unhz.eu
}

Received: October 1, 2020

Accepted: November 4, 2020

Online Published: December 22, 2020

doi:10.5430/ijfr.v11n6p348

URL: https://doi.org/10.5430/ijfr.v11n6p348

\begin{abstract}
From antiquity to modernization, the budget is portrayed as one of the main factors in economic and social life. This paper analyzes the relationship between education and budget management as a necessity for well-being and financial stability. This shows that the use of knowledge during the budget cycle management depends on the education and combination of many factors coming from the environment where the individual or family operates. Here it is explained how Cluster and MDS analysis in interaction with other statistical tests explain the similarities or the differences between the observation groups from Kosovo, Western Balkan countries and European Countries (KO \& EU \& WBC), related to emergency funds, saving, registration of transactions of revenues or expenditures, financial decision-making, control and budgetary practices. The research is argued from empirical findings giving a new approach through detailed recommendations for variables of observation groups on the personal budget.
\end{abstract}

Keywords: budget education, budget management, financial stability, cluster analysis, MDS analysis

JEL Codes: C38; D11; D12; D14; G5; G51

\section{Introduction}

The field of personal finance, including planning, consulting and financial importance, is a new and very important profession for the country's economy and financial stability (Warschauer, T, 2002). Previous studies have shown that individuals are not very prepared for these new loads and they often manage their finances poorly. In this case, researchers are doing more and more research related to personal budget management, in order to identify the best methods to help increase the financial well-being of society (Soyeon Sh. \& Xiao J. \& Barber B. \& Lyons A., 2009). The same contribution was made by the authors (Hilgert, M. A., Hogarth, J. M., \& Beverly, S. G., 2003) where according to them, financial education is important not only for individuals or individual families but also for society as a whole. While the importance for education and financial management continues to increase according to (Joo S., 2008), the situation, attitudes and financial behavior, cannot be evaluated to the same extent. The paper describes the necessity of financial-budgetary education and management for the sustainability of financial stability and the well-being of society in cooperation with other environmental factors. The elaboration of the empirical model was done through two econometric-statistical analyzes. First, based on study variables through Cluster analysis, the classification of surveillance groups (KO\&EU\&WBC) has been done, in order to see which groups in which variables have more knowledge and in which they should be improved. Second, the findings from the Cluster analysis are elaborated in the multidimensional measurement analysis to provide concrete recommendations through the S matrix for similarities and differences between states and variables. Finally, as stated in the abstract, the combination of these two analyzes through a new approach offers some notable features related to education and budget management, including the fact that financial stability tends to be stable for individuals who have greater education or financial awareness for the budget cycle unlike the other group.

\section{Scientific Literature Review}

Many studies argue that the personal budget depends on the behavior of the individual (Aguiar M \& Amador M, 2011), which includes expenditures and revenues divided into categories in certain time periods (weeks, months, years, etc.) (Nageeb, A., 2011), and which must be regulated in accordance with reasonable circumstances (Jamieson T. \& Jamieson P., 2009). Regarding (Item7 \& 14, i.e. variables in research), recommendations were given by many 
authors. Firstly, individuals during financial-budget planning need to analyze their current situation choose the right alternative and make decisions about their financial goals and capabilities, controlling revenue as well as ensuring proper management and long-term financial stability. From the ideas of (Gómez F., 2009) which emphasize the importance of financial education as a condition for providing knowledge, skills to adopt good money management practices, revenue generation, cost management, savings culture, and debt repayment care and even for investment. However, there are no absolute results on savings (Item12) considering other factors (educational level, income, country's economy, employment, etc.) affect financial-budgetary education (Bajtelsmit, V. \& Bernasek, A.\& Jianakoplos, A., 1999). According to (Karlan, D. \& Morduch, J, 2009), analyzed the differences between people with lower and higher incomes, where they emphasized that people with lower incomes have no savings account unlike the other group (Item4). According to the authors (King, G. \& Levine, R., 1993), (Beck T. \& Levine R.\& Loayza N., 2000), (Klapper L. \& Laeven L.\& Rajan R., 2006) and (Beck T. \& Demirguc-Kunt A. \& Levine R., 2007), they analyzed investments from the perspective of savings made by individuals (Item12 \& 9), all proved that the state should provide financial stability for the needs of the people, promoting innovation, or development culture to give them the opportunity to save, because by investing from their savings, they can generate profits and thus increase inheritance. Similar opinions have been given by (Bajtelsmit, V. \& Bernasek, A. \& Jianakoplos, A., 1999), (Bernheim D. \& Garrett M., 1996), (Scholtz J., 1992). In researches of (Sterns L., 1998), (Kotlikoff J. \& Morris N., 1989), (Ferraro F. \& Su P., 1999), (Kleinman, G. \& Anandarajan A. \& Lawrence K, 1999) and (Wiatrowski W., 1993), related to (Item 8) they proved that demographic factors have a big impact on saving money for retirement, recommending that most young people who are working should save money, due to new reforms that may come to retire. According authors (Bassett F. \& Fleming J.\& Rodrigues A, 1998), (Grable E. \& Lytton H., 1997) and (Mitchell S. \& Moore F., 1998), saving for the future until retirement depends on two important factors for this type of decision such as age and income of individuals. According to (Hershey A. \& Mowen C., 2000) that individuals between the ages of 35-88 have financial maturity in proportion to their age, which means that older people can make better financial decisions. This is contradicted by (Lee A., Xu Y., Hyde K.F., 1997), (Kahneman D. \& Tversky A, 1979) and (Yuh Y. \& Olson P., 1997) that the better financial decisions do not have only the elderly, but it depends on education and management, young people can do the same. Since they are young, they have more financial knowledge and are more likely to be offered various financial services, from which they can acquire new practices and knowledge for budget management (Item14\&3\&5). But, (Lewellen A. \& Lease C.\& Schlarbaum G., 1975), (Glass C. \& Kilpatrick B., 1998) and (Henkens K., 1999), they analyzed that marital status is the main factor, because family responsibility makes individuals more careful in managing and financial-budgetary education, in order to have a better financial stability and security for the future. But, (Karlan, D.\& Morduch, J., 2009), (Sonuga J. \& Webley P., 1993) and (Furnham, A., 1999), they emphasized that education or financial knowledge that people have during budget management affect financial stability and economic well-being, at the same time through their knowledge they can help family members or other people to increase financial-budgetary knowledge. Findings from the authors' research (Bernheim D. \& Garrett M., 1996), (Hilgert A. \& Hogarth M. \& Beverly G., 2003), (Lusardi, A., 2009) emphasize that financial education between youth and adult in the US is low. (Fry T. \& Mihajilo S. \& Russell R \& Brooks, R, 2008) (Meier, S. \& Sprenger, C., 2008), (Sherraden, M, 1991), (Schreiner, M., \& Sherraden, M., 2007), they analyzed that education and financial management have a positive effect on financial stability and well-being. The practice of financial-budgetary management, facilitate decision-making, information, saving, planning for the future (Jacobs L. \& Hershey, D., 2005), (Hershey A. \& Mowen C., 2000).

The rules of personal budget management according to useful commitments depend on the intensity of financial self-control (Item14), this theory matches the empirical findings (Galperti S., 2017). Financial education and management refers to software (PMF), which helps users manage their money, categorize financial transactions of income and expenses (Item10\&11), spending trends and net worth. (Amador, M \& Werning, I. \& Angeletos, M., 2006). Mathematical equation for good budget planning according to the symmetrical model:

$$
u^{1}(c: r)=u^{2}(c: r)=\ln (c)={ }_{-}^{r} 1={ }_{-}^{r} 2={ }_{-}^{r}>0, \bar{r} 1=\bar{r} 2=\bar{r}>{ }_{-}^{r} \text { and } v(s)
$$

To plan well we need to look at the overall environment:

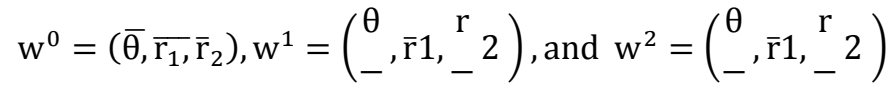

Their probabilities are $g \frac{1}{2}(1-g)$, remark 1 and symmetry imply that:

$$
s^{d}\left(w^{0}\right)<s^{d}\left(w^{1}\right)=s^{d}\left(w^{2}\right), c_{1}^{d}\left(w^{2}\right)=c_{2}^{d}\left(w^{1}\right)<c_{1}^{d}\left(w^{1}\right)=c_{2}^{d}\left(w^{2}\right), c_{1}^{d}\left(w^{0}\right)=c_{2}^{d}\left(w^{0}\right)
$$


Similar properties hold for personal budget $\left(c^{p}, s^{p}\right)$ in this case we emphasize that it exists $\beta<1$ sufficiently high, that $s^{d}\left(w^{1}\right)=s^{d}\left(w^{2}\right)>s^{p}\left(w^{0}\right)$.

\section{The Purpose of the Research}

The purpose of this research is to provide new valuable to education and budget management as a necessity of well-being and financial stability. Where after a period of 1-2 years with same observation, the research will be done again to see if the analysis and recommendations have influenced the improvement or not. Another purpose is to understand how important financial education is to respondents, in which variables are the best or not, in which variables are interrelated and is there a difference between the groups in most variables.

\section{Scope of the Study and the Collection of Data}

The research was conducted through questionnaires with respondents from Kosovo's cities, Western Balkan countries and European countries and beyond (18 states). The questionnaire focus was based on previous research related to the two methods involved, based on Likert measurements which are divided into the general question's session and the questions of education and management of the budget. After data is collected it is used to figure out the methods and tests that suits the research.

\section{Methods}

The Cluster Analysis (k-means) and the multidimensional measurement analysis (MSD-Alscal) methods, are used for making connections with the tests or methods that are suitable for these two analyzes and research as (Ch-square, Anova, Crosstab, Principal Component Analysis) the research was conducted with all respondents. So, in order for the research to be as important as possible, we first rely on the theory of these analyzes. Cluster analysis is a statistical method with lot of variables which makes classification of data according to similarities, (Hastie, T \& Tibshirani, R \& Friedman J, 2017), according to groups algorithms (Yuan, Ch \& Yang, H, 2019), as well as according to maximum expectations (Ankerst, M. et Al, 1999). This analysis fits with each field of research (Morissette, L \& Chartier, L, 2013). Going back to the idea of (Steinhaus, H, 1957) the term "k-means" was first used by (MacQueen, 1967). The techniques they have used in the model are MacQueen algorithm and Hartigan \& Wong algorithm, in which case the solution of algorithm depends on the characteristics of data as well as sample size, number of variables etc. Jain, Duin \& Mao even suggest trying some algorithms, to gain the best possible understanding of the database (Lloyd, 1982).

A Cluster analysis is efficient and effective if it involves as few groups as possible and should be statistically important (Sig.000). All respondents and variables are divided into three groups ( $\mathrm{k}=3$ ), as (KO-Kosovo, EU-European countries and beyond, WBC-Western Balkan countries), the closer the groups are to each other, the more similar they are considered. To calculate the similarities between these groups is used the distance Euclidian:

$$
\mathrm{dE}=\sqrt{\sum_{\mathrm{i}}^{\mathrm{k}}\left(\mathrm{c}_{\mathrm{i}}-\mathrm{x}_{\mathrm{i}}\right)^{2}}
$$

Where (c) is the center of the group, (x) presents the comparison of groups (KO\&EU\&WCB), ( $\mathrm{i}$ or $\mathrm{c}$ ) is the dimension $(\mathrm{x})$, and $(\mathrm{k})$ is the total number of dimensions. $(\mathrm{n}=125-3=122 / 2.47435$, means 3observations $=2.47$.

Square distance Euclidian for model is:

$$
\mathrm{dE}^{2}=\sum_{\mathrm{i}}^{\mathrm{k}}\left(\mathrm{c}_{\mathrm{i}}-\mathrm{x}_{\mathrm{i}}\right)^{2}=0.2763
$$

Also, in k-means is used Manhatan distance:

$$
\mathrm{dMht}=\sum_{\mathrm{i}}^{\mathrm{k}}\left|\mathrm{c}_{\mathrm{i}}-\mathrm{x}_{\mathrm{i}}\right|
$$

or maximum distance between vector attributes:

$$
\operatorname{dMax}_{\mathrm{i}}=1, \ldots, \mathrm{k}=\sum_{\mathrm{i}} \mid \mathrm{c}_{\mathrm{i}}-\mathrm{x}_{\mathrm{i}}
$$

Algorithm (k-means) represents minimizing the amounts of variances within the groups $(n=3)$ through equation

$$
\mathrm{E}=\sum_{\mathrm{i}}^{\mathrm{k}} \sum_{\mathrm{j}=1}^{\mathrm{ni}}\left\|\mathrm{X}_{\mathrm{ij}}-\mathrm{C}_{\mathrm{i}}\right\|^{2}
$$

$\left(\mathbf{n}_{\mathbf{i}}\right)$ is the number of cases included in group (k) and $\sum_{1}^{\mathrm{k}} \mathrm{ni}=\mathrm{n}$, is the technique of the collection of (k)groups for 
minimizing variances (125R).

Mathematically k-means analysis is a model that is evaluated through maximum probabilities. Equation for research of budget education and management:

so $\left(\mathrm{R}^{\mathrm{d}}\right)$

$$
\left[x_{1}, x_{2}, \ldots . x_{n}\right] \in \mathrm{R}^{\mathrm{d}}
$$

is data space with dimensions $(\mathbf{d})$.

$$
\mathrm{C}=\left[\mathrm{c}, \mathrm{c}_{2}, \ldots . \mathrm{c}_{\mathrm{n},}\right] \in \mathrm{R}^{\mathrm{d}}
$$

Equation nr. (10) helps to minimize and solve the problem of budget management for three groups.

$$
E=\sum_{i=1}^{k} \sum_{j=1}^{n} d\left(C_{i}, X_{i j}\right)
$$

Equation nr. (11) is the discrete distribution in research.

$$
E=\sum_{i=1}^{k} p(x) d\left(c_{i} X_{i j}\right) \mathrm{d}_{\mathrm{x}}
$$

Represents the continuous distribution to the model, $\mathrm{p}(\mathbf{x})$ is the probability density function and (d) is the distance function between cases ns variables.

These steps are included when applying the Cluster analysis: solution of number of groups (n), matric solution that will be used, selecting the method for finding the center of the initial groups, determining the centers of the initial groups $\mathbf{C}\left(\boldsymbol{R}^{\boldsymbol{d}}\right)$, metric threshold (groups, cases): a) For i $<=\mathrm{nb}$ cases (respondents for three observations), assigning the closest group, b)a repeated of group centers until the center of group not to be changed within tolerance criterion. Algorithm of budget education and management seeks to divide data into optimal amounts within errors (SEE)groups through the equation:

$$
\boldsymbol{S} E E 2=\frac{N_{i} \sum_{j}|| x_{i j}-\left.c_{i}\right|^{2}}{N_{i}-1}=S E E 1=\frac{N_{1} \sum_{j} \| x_{1 j}-\left.c_{1}\right|^{2}}{N_{1}-1}
$$

If the sum of (SSE2) for all variables is $(\mathrm{i} \neq 1)$ smaller than current one (SSE1), than the data belongs to this group

$$
S E E 2=\frac{N_{i} \sum_{j}|| x_{i j}-\left.c_{i}\right|^{2}}{N_{i}-1}=S E E 1=\frac{N_{1} \sum_{j} \| x_{1 j}-\left.c_{1}\right|^{2}}{N_{1}-1}
$$

For evaluation within research group(cluster), is used the Dunn index (1979) through equation:

$$
D I=\min _{i=1 \ldots m}\left\{\min _{j=1 \ldots m, i \neq j}\right\}\left\{\frac{d\left(c_{i}, c_{j}\right)}{\max _{k=1 \ldots m} \Delta k}\right\}
$$

So, $\boldsymbol{d}\left(\boldsymbol{c}_{\boldsymbol{i}}, \boldsymbol{c}_{\boldsymbol{j}}\right)$, is the distance between centers of the groups, which can be calculated with any of the equations presented before and $(\boldsymbol{\Delta} \boldsymbol{k})$ is the measure of the internal variation of groupings. The highest Dann index, says that the solution is important, it means the greater distance value, the closer the groups are to each other. Linear combination of d-dimensional distribution of Gauss according to group centers is found through logarithm equation

$$
J=\frac{|A \cap B|}{|A \cup B|}
$$

This algorithm was first explained by Dempster, Laird \& Rubin (1977), who aims to minimize.

$$
G E M=-\sum_{i=1}^{n} \log \left(\sum_{j=1}^{k} p\left(x_{1} \mid c_{j}\right) p\left(c_{j}\right)\right)
$$

Where $\left(\boldsymbol{p} \boldsymbol{x}_{\mathbf{1}} \mid \boldsymbol{c}_{\boldsymbol{j}}\right)$, is probabilityod $\left(\mathrm{x}_{\mathrm{i}}\right)$ (cases), taking into consideration thus it ingenerated by a Gaussian distribution that has $\left(c_{j}\right)$, as a center group, and $p\left(c_{j}\right)$, is the preliminary probability of this research center. The other way of calculating is also through Bayes rules

$$
m\left(c_{j} x_{i}\right)=\frac{p\left(x_{i} \mid c_{j}\right) p\left(c_{j}\right)}{p\left(x_{i}\right)}
$$


Implementation of Anova (ch-square, crosstab, sub-groups through Tukey and Bonferroni) help the model, to see which groups are different from each other to verify or not hypothesis. During the use of Cluster analysis controls are made so that the results to be important, $\mathrm{k}=3$ to the model shows that group number 1 is located between the two groups. K-means is closely related to non-parametric hypothesis tests (Brian, K \& Michael J, 2012). To give details recomamendations to the Cluster analysis model for the cases ans variables help us multidimensional measurement Analysis (MDS) which is very useful statstical method for detecting relationshpis and distance between cases, with a configuration of pints drawn in an abstract Kartezian space. (Mead, A, 1992). The analysis algorithm places each object in the n-dimensional space, in order to keep the distance between the variables of education and budget management as best as possible. For $\mathrm{N}=1,2$ and 3, the resulting points can be visualized in a scatter plot (Borg, I. \& Groenen, P, 2005). This analysis is otherwise known as key coordinate analyses or Torgerson-Gower scaling, in which case the input matrix shows the difference between the cases and the variables of this research, showing the differences that have come out from results.

Matrix (Ko \& Eu \& WBC) or $\mathrm{D}=\left[\mathrm{d}_{\mathrm{ij}}\right]$ where, $\left(\mathrm{d}_{\mathrm{ij}}\right)$ is the distance between the coordinates if (i) and (j), taking into consideration this, we have equation:

$$
d_{i j} \sqrt{\left(x_{i}-x_{j}\right)^{2}+\left(y_{i}-y_{j}\right)^{2}}
$$

to find the functions of research distance we use the equation:

$$
\operatorname{Strain}_{D}\left(x_{1}, x_{2}, \ldots, x_{N}\right)=\left(\frac{\Sigma_{i j}\left(b_{i j}-\left(x_{i}, x_{j}\right)\right)^{2}}{\Sigma_{i j} b_{i j}^{2}}\right)^{\frac{1}{2}}
$$

$\boldsymbol{b}_{i j}$, are the topics of the matrix for three observations(B), defined in the step number 2 of the algorithm. The matrix of coordinate ( $\mathrm{x}$ ) can be derived from the decomposition of the value of Eigen ( $\mathrm{B}=\mathrm{XX}$ '), while (B) matrix can be calculated from the proximity matrix (D) using the double centers of variables and cases (Wickelmaier, F, 2003). The model of this analysis is to verify the groups $(\mathrm{C} 1, \mathrm{C} 2, \mathrm{C} 3)$ has gone through steps as below:

1. Placing the matrix of the square proximity $\mathrm{D}^{(2)}=\left[\mathrm{d}_{\mathrm{ij}}^{2}\right]$,

2. Application of double concentration $B=\frac{1}{2} J^{(2)} J$, using the center of matrix $J=I-\frac{1}{n} 11^{\prime}$, where (n) is number of cases,

3. Are determined the largest value $(\mathrm{m})$ for $\lambda_{1}, \lambda_{2} \ldots \lambda_{m}$, amd the corresponding Eigen vectors $\left(\boldsymbol{e}_{1}, \boldsymbol{e}_{2} \ldots \boldsymbol{e}_{\boldsymbol{m}}\right)$, of (B), where (m) is the number of desired dimensions output results,

4. Now, $\mathrm{X}=\mathrm{E}_{\mathrm{m}} \Delta_{\mathrm{m}}^{1 / 2}$, where $\left(E_{m}\right)$ is matrix of (m) for value of vector, and $\left(\Delta_{m}\right)$ is the diagonal matrix of $(\mathrm{m})$ Eigen value of $(\mathrm{B})$ for education and management of budget.

$$
\begin{gathered}
\operatorname{Stress}_{D}\left(x_{1}, x_{2}, x_{N}\right)=\left(\sum_{i \neq j=1 \ldots N}\left(d_{i} j-\left\|x_{i}-x_{j}\right\|\right)^{2}\right)^{\frac{1}{2}} \\
\text { Or } \\
\operatorname{Stress}_{D}\left(x_{1}, x_{2}, x_{N}\right)=\left(\frac{\Sigma_{i j}\left(\Sigma_{i j}-\left\|x_{i}-x_{j}\right\|\right)^{2}}{\Sigma_{i, j} d_{i j}^{2}}\right)^{\frac{1}{2}}
\end{gathered}
$$

Where, (p: $\left.d_{i j}^{0}\right)$ and $\left.-d_{i j}^{2}\right)$ controlled exponent for distance. The data which will be analyzed (KO, EU, WCB) or n marked with (M) on which is determined the distance function ( $\mathrm{dij}=$ the distance between cases, variables (i) and (y) ).Below is the matrix equation in the absence of similarity

$$
\mathrm{D}:=\left(\begin{array}{ccc}
\mathrm{d}_{1,1}, & \mathrm{~d}_{1,2} & \ldots . . \mathrm{d}_{1, \mathrm{M}} \\
\mathrm{d}_{2,1}, & \mathrm{~d}_{2,2}, & \ldots . \mathrm{d}_{2, \mathrm{M}} \\
\mathrm{d}_{\mathrm{M}, 1}, & \mathrm{~d}_{\mathrm{M}, 2}, & \ldots . . \mathrm{d}_{\mathrm{M}, \mathrm{M}}
\end{array}\right)
$$

As mentioned above that the purpose is to find similarities or distances

and to give recommendations for the future, 
in this case(D) to find (M) vectors $\left(x_{1}, \ldots, X_{M} \in R^{N}\right.$ as $\left\|x_{i}-x_{j}\right\| \approx d_{i, j} f_{i, j} \in 1, \ldots, M$. Otherwise this matrix is known as the Euclidian distance. (Kruskal, J. B \& Wish, M., 1978). Direct approach of analysis $Q=N(N-1) / 2=$ $125(125-1) / 2,100(100-1) / 2,2(2-1) / 2$. Where $(\mathrm{Q})$, is number of variables, $(\mathrm{N})$ is number of cases. The software for running the procedure is available in many statistical packages. There is an often a choice between matrix and non-matrix MDS (Kruskal, J. B, 1964). The dimensions of budget education and management is $(2,2)$, level of measurement (interval), model scale (Euclidean distance), matrix of data (stress convergence 0.001, minimum stress value 0.005). Tools of selection of model as AIC / BIC, Bayes factors or cross verification to be useful for choosing the dimensioning that balances the model.

Theorem of Pythagoras about right triangle:

$$
a^{2}+b^{2}=c^{2} \Rightarrow \sqrt{a^{2}+b^{2}}=c
$$

$d_{2,3}=\left[|6.654-0|^{\dot{2}}+|5.252-5.190|^{2}\right]^{\frac{1}{2}}=6.6537$ (distances between EU, WBC).

$\mathrm{N}=3$ cluster $(\mathrm{KO}, \mathrm{EU}, \mathrm{WBC})$,

$$
\begin{gathered}
\mathrm{C} 1=(4.409, .418, .000, .274, .128, .000) \\
\mathrm{C} 2=(4.803, .706, .193, .214, .036, .000) \\
\mathrm{C} 3=(4.111, .586, .225, .284, .000, .000) \\
\mathrm{d}(\mathrm{D}, \mathrm{C} 1)=\sqrt{(1-4.409)^{2}+(2-.418)^{2}+(3-.000)^{2}+(4-.274)^{2}+(5-.128)^{2}+(6-.000)^{2}} \\
\mathrm{~d}(\mathrm{D}, \mathrm{C} 2)=\sqrt{(1-4.803)^{2}+(2-.706)^{2}+(3-.193)^{2}+(4-.214)^{2}+(5-.036)^{2}+(6-.000)^{2}} \\
\mathrm{~d}(\mathrm{D}, \mathrm{C} 3)=\sqrt{(1-4.111)^{2}+(2-.586)^{2}+(3-.225)^{2}+(4-.284)^{2}+(5-.000)^{2}+(6-.000)^{2}} \\
D:=\left(\begin{array}{c}
9.84 \\
9.95 \\
9.70
\end{array}\right)
\end{gathered}
$$

\section{Results and Discussions}

\subsection{Hypotheses}

Null and alternative hypotheses which test the validity of the model can be written as follows:

\section{$H_{0}$ : There is no difference between the observation groups related with budget education and budget financial management.}

$H_{A}$ : There is difference between the observation groups related with budget education and budget financial management.

$$
\begin{aligned}
& \text { if } x^{2}>x_{\alpha(r-1) \alpha(c-1)}^{2}-H_{0} \text { rejected ana accepted } H_{A} \\
& \text { if } x^{2}<x_{\alpha(r-1) \alpha(c-1)}^{2}-H_{0} \text { accepted and rejected } H_{A}
\end{aligned}
$$

The purpose of these hypotheses is to see if there is a difference in any of the observations $(\mathrm{C} 1, \mathrm{C} 2, \mathrm{C} 3)$ in most of variables, especially in education and management variables. So that through differences of groups and recommendations coming out from MDS analysis to help individuals and family economies regarding the personal budget.

6.2 Cluster Analysis

Table 1. Iteration history \& PCA-Cluster analysis

\begin{tabular}{lccclll}
\hline \multirow{2}{*}{ Iteration } & \multicolumn{9}{c}{ Change in Cluster Centers } & $\begin{array}{l}\text { Principal } \\
\text { Analysis }\end{array}$ & Component & Analysis- Cluster \\
\cline { 2 - 7 } 1 & 1 & 2 & 3 & $\begin{array}{l}\text { Kaiser-Meyer-Olkin } \\
\text { of Sampling }\end{array}$ & Measure & .859 \\
& 4.409 & 4.803 & 4.111 & & &
\end{tabular}




$\begin{array}{llllll}2 & .418 & .706 & .586 & \text { Adequacy. Approx. Chi-Square } & 1588.31 \\ 3 & .000 & .193 & .225 & \mathrm{df} & 91 \\ 4 & .274 & .214 & .284 & \text { Sig. } & .000 \\ 5 & .128 & .036 & .000 & & \\ 6 & .000 & .000 & .000 & & \end{array}$

Table 1, represents the maximum change of absolute coordinates for each center in value .000, where during three repeats were made 6 observations, the difference between them is $11.000(\mathrm{C} 1, \mathrm{C} 2$, C3), while through PCA (principal component analysis) represents the verification of the Cluster model for .859 or $\mathbf{8 6 \%}$ and Sig. .000 .

Table 2. Final cluster centers

\begin{tabular}{ccccc}
\hline No. & Variables & \multicolumn{3}{c}{ Cluster } \\
& & KO & EU & WBC \\
\hline Item1 & Gender & 2 & 2 & 2 \\
Item2 & Age & 3 & 2 & 3 \\
Item3 & Profession & 6 & 2 & 7 \\
Item4 & Incomes & 3 & 3 & 3 \\
Item5 & Sufficient information to make financial budget decisions & 2 & 4 & 3 \\
Item6 & Awareness of the importance of financial assurance & 3 & 5 & 4 \\
Item7 & Proper planning for the budgetary financial future & 2 & 3 & 3 \\
Item8 & Saving money as an assistance after retirement & 2 & 3 & 4 \\
Item9 & Creating an emergency fund to overcome crises or meeting & 2 & 4 & 3 \\
& budgetary financial needs for 1 to 12 months, in a case of & & & \\
Item10 & loss of work or ability to work for a while. & & & \\
Item11 & Registration of all transactions for budget revenues & 2 & 5 & 3 \\
Item12 & Registration of all transactions for budget expenditures & 2 & 4 & 3 \\
Item13 & Saving and investing is important for better well-being & 3 & 4 & 4 \\
Item14 & The need for a financial advisor & 3 & 3 & 3 \\
\hline
\end{tabular}

Table 2, presents the final data of the groups regarding education and budgetary financial management as a necessity for welfare and financial stability through three observations in 14 variables. The first survey included respondents from countries of Kosovo (KO), in the second group respondents from European (EU) countries and beyond, and in the third survey are included respondents from Western Balkan countries (WBC). To all three countries (KO\&EU\&WBC), Item1 emphasize that both genders need to increase self-awareness for budget management, but at the same time both genders can be good budget managers in a case of budget awareness. Item2(KO\&WBC) emphasize that age is important for budget management, (EU) emphasize that age it is not important but the budget awareness of the age group. To the Item3the greatest response gave (WBC), which says the profession is important for increasing knowledge about financial management, than is $(\mathrm{KO})$, and in the end (EU) gives low rating that emphasizes that the profession does not have an important role if people have better or weak knowledge and management, this depends on their interest in how much they want to be educated about budget management. Item 4 all three observations have the same opinion that education and management helps to realize and save incomes, it means that welfare and financial stability do not depend on the amount of income but on education and budget management.Item5, the highest value is in (EU) while (WBC \& $\mathrm{KO}$ ) has less information about making financial decisions. Item6, higher value for the importance of financial ansurance has (EU), then to (WBC) and (KO). Item7, better planning for the financial future they do $(\mathrm{EU} \& \mathrm{WBC})$, but even $(\mathrm{KO})$ is not too far from the first two observations. Item8, regarding savings as assistance after retirement the highest value have the countries of (WBC), then (EU) countries. Item9, the emergency funds in extreme cases are more liked from (EU) countries, than (WBC\&KO). Item $10 \& 11$ for the registration of all transactions for income and expenses (KO) has the lowest 
average, after (KO) is (WBC) and the highest average has (EU). To item12, more interest have (EU \& WBC) but also (KO) it is not too far from them in the interest of savings and investment. Item13, the need for a financial advisor in the three surveys (KO \& EU \& WBC) has the same average. Item14, practice and smaller budgetary financial control has $(\mathrm{KO})$ and the higher value has (EU).

Table 3. Distance between final cluster centers

\begin{tabular}{llll}
\hline Cluster & KO & EU & WBC \\
\hline 1 & & 6.654 & 5.190 \\
2 & 6.654 & & 5.252 \\
3 & 5.190 & 5.252 & \\
\hline
\end{tabular}

Table 3, presents the distance between the three groups, in this case (EU\&WBC) are closer, and the group (KO) is located between them. $d_{2,3}=d_{2,3}=\left[|6.654-0|^{2}+|5.252-5.190|^{2}\right]^{\frac{1}{2}}=\mathbf{6 . 6 5 3 7}$.

\subsection{Anova-Culter Analysis}

Table 4. Anova- Culter analysis

\begin{tabular}{|c|c|c|c|c|c|c|}
\hline \multicolumn{7}{|c|}{ ANOVA-Cluster Analysis } \\
\hline & & Sum of Squares & df & Mean Square & $\mathrm{F}$ & Sig. \\
\hline \multirow[t]{3}{*}{ Item 1} & Between Groups & .250 & 2 & .125 & .495 & .001 \\
\hline & Within Groups & 80.366 & 318 & .253 & & \\
\hline & Total & 80.617 & 320 & & & \\
\hline \multirow[t]{3}{*}{ Item 2} & Between Groups & 51.883 & 2 & 25.941 & 35.356 & .000 \\
\hline & Within Groups & 233.320 & 318 & .734 & & \\
\hline & Total & 285.202 & 320 & & & \\
\hline \multirow[t]{3}{*}{ Item 3} & Between Groups & 1961.807 & 2 & 980.904 & 691.268 & .000 \\
\hline & Within Groups & 451.239 & 318 & 1.419 & & \\
\hline & Total & 2413.047 & 320 & & & \\
\hline \multirow[t]{3}{*}{ Item 4} & Between Groups & 18.138 & 2 & 9.069 & 7.644 & .001 \\
\hline & Within Groups & 377.270 & 318 & 1.186 & & \\
\hline & Total & 395.408 & 320 & & & \\
\hline \multirow[t]{3}{*}{ Item 5} & Between Groups & 124.925 & 2 & 62.463 & 100.777 & .000 \\
\hline & Within Groups & 197.100 & 318 & .620 & & \\
\hline & Total & 322.025 & 320 & & & \\
\hline \multirow[t]{3}{*}{ Item 6} & Between Groups & 141.727 & 2 & 70.863 & 91.800 & .000 \\
\hline & Within Groups & 245.476 & 318 & .772 & & \\
\hline & Total & 387.202 & 320 & & & \\
\hline \multirow[t]{3}{*}{ Item 7} & Between Groups & 93.919 & 2 & 46.960 & 54.565 & .000 \\
\hline & Within Groups & 273.676 & 318 & .861 & & \\
\hline & Total & 367.595 & 320 & & & \\
\hline \multirow[t]{3}{*}{ Item 8} & Between Groups & 83.791 & 2 & 41.896 & 36.067 & .000 \\
\hline & Within Groups & 369.393 & 318 & 1.162 & & \\
\hline & Total & 453.184 & 320 & & & \\
\hline Item 9 & Between Groups & 48.301 & 2 & 24.150 & 21.864 & .000 \\
\hline y Sciedu & & 355 & & & N 1923-4023 & E-ISS \\
\hline
\end{tabular}




\begin{tabular}{|c|c|c|c|c|c|c|}
\hline \multirow{5}{*}{ Item 10} & Within Groups & 351.257 & 318 & 1.105 & & \\
\hline & Total & 399.558 & 320 & & & \\
\hline & Between Groups & 90.810 & 2 & 45.405 & 59.863 & .000 \\
\hline & Within Groups & 241.196 & 318 & .758 & & \\
\hline & Total & 332.006 & 320 & & & \\
\hline \multirow{3}{*}{$\begin{array}{c}\text { Item } \\
11\end{array}$} & Between Groups & 132.834 & 2 & 66.417 & 89.097 & .000 \\
\hline & Within Groups & 237.054 & 318 & .745 & & \\
\hline & Total & 369.888 & 320 & & & \\
\hline \multirow{3}{*}{$\begin{array}{c}\text { Item } \\
12\end{array}$} & Between Groups & 23.713 & 2 & 11.857 & 18.818 & .000 \\
\hline & Within Groups & 200.368 & 318 & .630 & & \\
\hline & Total & 224.081 & 320 & & & \\
\hline \multirow{3}{*}{$\begin{array}{c}\text { Item } \\
13\end{array}$} & Between Groups & 19.322 & 2 & 9.661 & 5.350 & .005 \\
\hline & Within Groups & 574.229 & 318 & 1.806 & & \\
\hline & Total & 593.551 & 320 & & & \\
\hline \multirow{3}{*}{$\begin{array}{c}\text { Item } \\
14\end{array}$} & Between Groups & 122.662 & 2 & 61.331 & 61.062 & .000 \\
\hline & Within Groups & 319.401 & 318 & 1.004 & & \\
\hline & Total & 442.062 & 320 & & & \\
\hline
\end{tabular}

Table 4, presents the value of Sig. .000 $<.005$, which shows that there is a difference between the groups (KO \& EU $\&$ WBC) in variables and measured research cases, the same thing was confirmed by Post Hoc test.

\subsection{Cluster-Chi Square}

Table 5. Cluster (Chi-Square)

\begin{tabular}{lccccccccc}
\hline & Item 1 & Item 2 & Item 3 & Item 4 & Item5 & Item 6 & Item 7 & Item 8 & Item 9 \\
\hline Chi-Square & $187.72^{\mathrm{a}}$ & $142.76^{\mathrm{b}}$ & 151.03 & $80.93^{\mathrm{c}}$ & $162.04^{\mathrm{c}}$ & $124.51^{\mathrm{c}}$ & $144.39^{\mathrm{c}}$ & $95.877^{\mathrm{c}}$ & $83.315^{\mathrm{c}}$ \\
df & 2 & 7 & 4 & 4 & 4 & 4 & 4 & 4 & 4 \\
Sig. & .000 & .000 & .000 & .000 & .000 & .000 & .000 & .000 & .000
\end{tabular}

a. 0 cells $(0.0 \%)$ have expected frequencies less than 5. The minimum expected cell frequency is 108.0.

b. 0 cells $(0.0 \%)$ have expected frequencies less than 5 . The minimum expected cell frequency is 40.5 .

c. 0 cells $(0.0 \%)$ have expected frequencies less than 5 . The minimum expected cell frequency is 64.8 .

Table 6. Cluster (Chi-Square)

\begin{tabular}{|c|c|c|c|c|c|c|}
\hline & Item 10 & Item 11 & Item 12 & Item 13 & Item14 & $\begin{array}{l}\text { Distance of Case from its Cluster Number } \\
\text { Classification Cluster Center of Case }\end{array}$ \\
\hline Chi-Square & 144.704 & 184.981 & $238.455^{\mathrm{d}}$ & 116.340 & 101.309 & $146.748^{f}$ \\
\hline $\mathrm{df}$ & 4 & 4 & 4 & 4 & 4 & 120 \\
\hline Sig. & .000 & .000 & .000 & .003 & .000 & .000 \\
\hline
\end{tabular}

Tables $5 \& 6$, present the results according to which there is no linear relationship between respondents of different 
countries regarding education and management as a necessity for well-being and financial stability at the level of importance Sig.000 $(\mathrm{P}<.005)$, this means that education and management are different, but the goal is the same for raising awareness about budget management, and especially for (KO\&WBC). Observations and expectations different from each other (108, 40.5, 64.8, 64.2, 82.7, 107. 0 Exp.).

$$
x^{2}>x_{\alpha(r-1) \alpha(c-1)}^{2}
$$

Item1 (187.722> 108.0.), Item2(142.765>40.5), Item3 (151.031), Item4(80.938>64.8), Item5 (162.04>64.8), Item6(144.395> 64.8), Item7(144.395>64.8), Item8(95.877>64.8), Item9(83.315>64.8), Item10(144.704), Item11(184.981), Item12(238.455>64.2), Item13(116.340), Item14 (101.309). $x^{2}>\rightarrow$ Rejected $\mathrm{H}_{0}$ and confirmed $\mathrm{H}_{\mathrm{A}}$.

\subsection{MDS- Cluster Analysis}

Above were emphasized the characteristics of respondents for (KO\&EU\&WBC) in the level.005, where the differences between them were emphasized. In this case in order to give recommendations for the three Cluster observations as mentioned in the methodology, is used the analysis for multidimensional measurement for respondents and variables. Measurements were initially made respondents-variables, then measurements between variables. This method helps increase education and improve management in all respondents or beyond.

Table 7. MDS-Cluster analysis

\begin{tabular}{|c|c|c|c|c|c|}
\hline \multicolumn{6}{|c|}{ MDS- CLUSTER ANALYSIS } \\
\hline \multicolumn{3}{|c|}{ Between respondents (cases) } & \multicolumn{3}{|c|}{ Between variables } \\
\hline \multicolumn{3}{|c|}{ Young's S-stress formula 1 is used. } & \multicolumn{3}{|c|}{ Young's S-stress formula 1 is used. } \\
\hline Iteration & $\mathrm{S}$-stress & Improvement & Iteration & S-stress & Improvement \\
\hline 1 & .33828 & & 1 & .28664 & \\
\hline 2 & .27702 & .06125 & 2 & .24673 & .03990 \\
\hline 3 & .27222 & .00480 & 3 & .24530 & .00143 \\
\hline 4 & .27188 & .00034 & 4 & .24503 & .00027 \\
\hline \multicolumn{3}{|c|}{ Iterations stopped because } & \multicolumn{3}{|c|}{ Iterations stopped because } \\
\hline \multicolumn{3}{|c|}{ S-stress improvement is less than .001000} & \multicolumn{3}{|c|}{ S-stress improvement is less than .001000} \\
\hline \multicolumn{3}{|c|}{ For matrix } & \multicolumn{3}{|c|}{ For matrix } \\
\hline Stress $=$ & 145 & $=.7749$ & Stress $=$ & 819 & $Q=.80490$ \\
\hline
\end{tabular}

Table 7 shows that $\mathrm{k}=2$ has stopped at iteration 4 , because the result has been achieved $\mathbf{. 0 0 0 3 4}$ in the case between respondents (KO \& EU \& WBC), while in the case between variables (Item 1-14) iteration has stopped at .00027. Z statistic in both cases are close to zero which means that the choice of these variables is appropriate to give recommendations. The value of the Stress matrix according to the Crusal formula for the respondents is $\mathbf{0 . 7 7 4 9 3}$ and for variables it is $\mathbf{0 . 8 0 4 9 0}$, according to these matrices related to education and budget management as a necessity for welfare and financial stability budget management (KO\&EU\&WBC) explained for $\mathbf{7 7 \%}$ and $\mathbf{8 0 \%}$. 

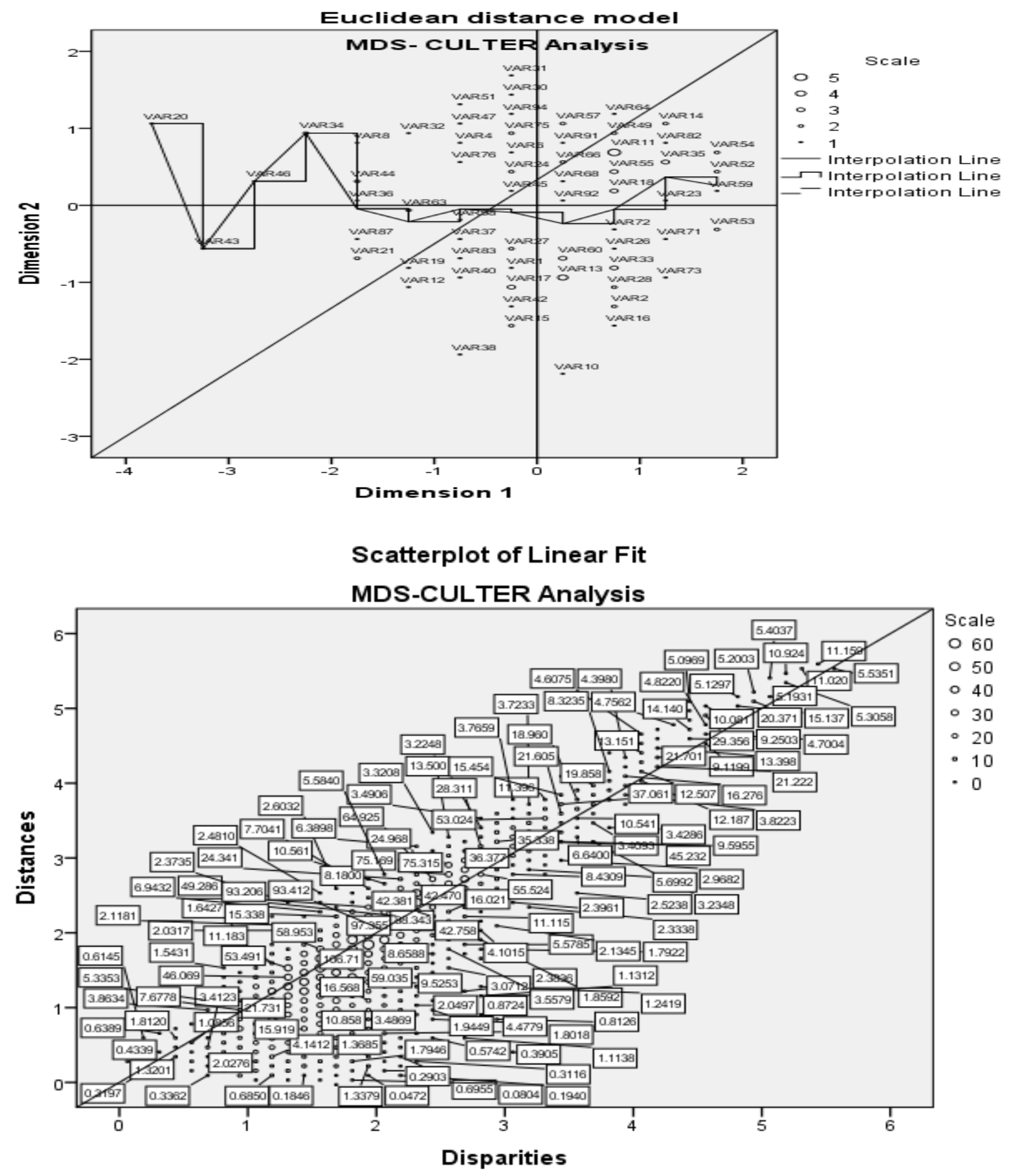

Figure 1. Euclidean distance (between respondents)

Figure 1, indicates that the ideal point for (KO \& EU \& WBC), $\mathbf{y}=\mathbf{0 . 8 3 3 3} * \mathbf{x}+\mathbf{0 . 3 3 3 3}$, located in the part $0-2$. Respondents who have similarities are $(11,13,60,16,35,18,55$, and 33). The respondents with the largest differences are $(20,43)$, also respondents $(21,87,38)$ are in the same group, but far from the general trend. Respondents with code $(10,31)$ are farther from the ideal point and have very different perceptions. So, from the graph it is seen that respondents with code (10- Switzerland, 38-Croatia, 43-Malta, 20-Montenegro, 31-Kosovo, 
64-Norvey, 54-Austria, 78-England), shows differences from general trend. According to scatterplot of linear fit, the predicated distances correspond to the true value $\mathbf{Z}=. \mathbf{7 7}$.
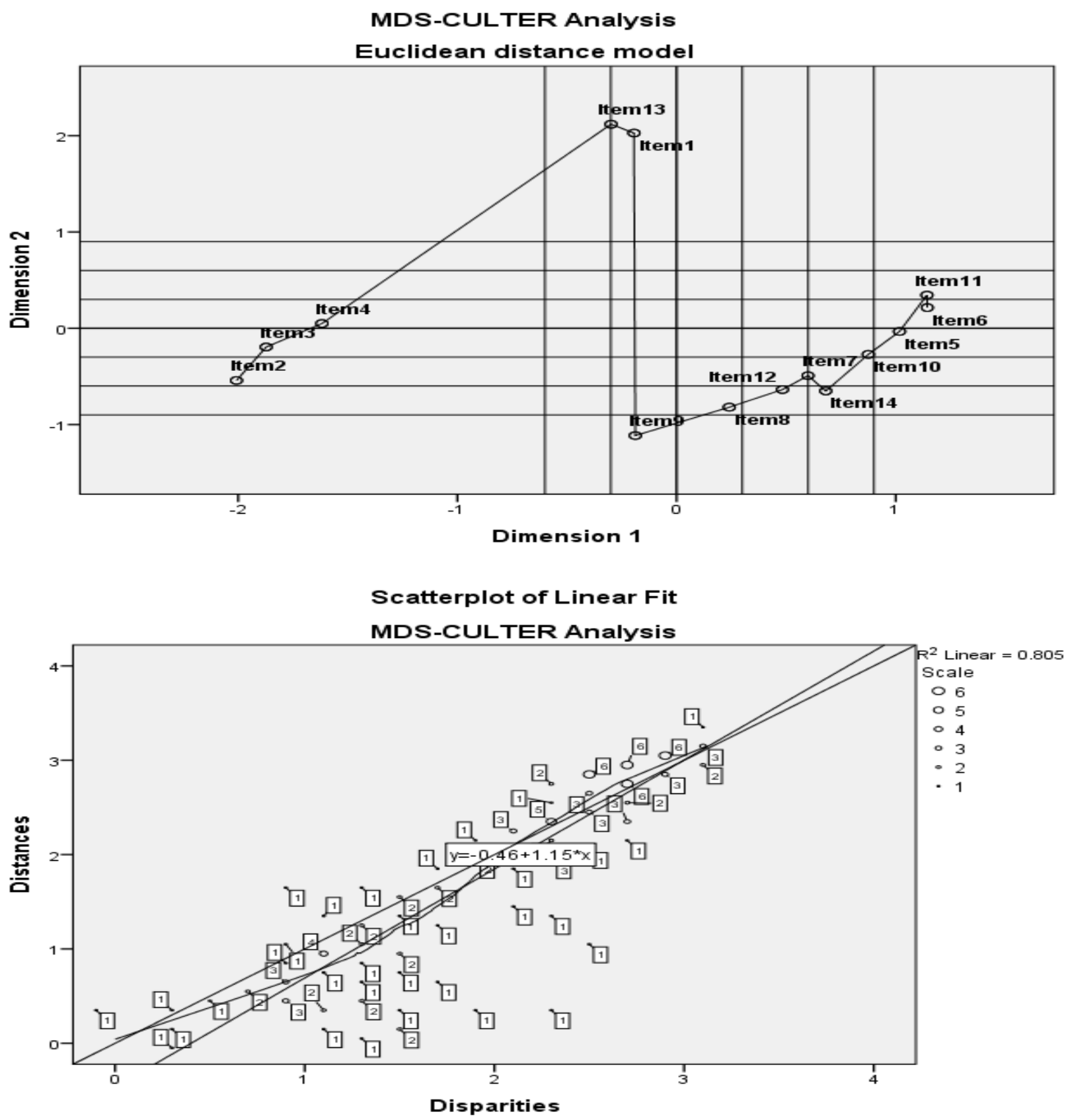

Figure 2. Euclidean distance (between variables)

Figure 2, shows that ideal point for all variables (Item 1-14) in the both dimensions (1\&2) is $\mathbf{y = 1} \mathbf{1} \mathbf{x}+\mathbf{0}$. From the graph in both dimensions we have these recommendations: 1) in dimension 1 between variables: Item 9,1,13 (in order to create an emergency fund for overcoming crises, both genders need a financial advisor). Item 12,7 (proper planning helps save and invest), Item 14,7,10(located within limits of the variable 14, proper planning is don if respondents have budgetary practice and control the budget by recording budget revenues). Item $5,6,11$ (in order to have well-being and financial stability, respondents must have accessible information for making decision, awareness of financial assurance as well as recording expenses). 2) In the dimension between variables: Item 
$2,12,7,10$ (education of age group helps save and invest, proper planning for the future, as well as registration of budget revenue transactions). Item 3, 5(all professions must have sufficient information to make budgetary financial decisions, it means it does not depend on the profession but the desire for budget management information). Item 4,6, 11(respondents from their income must record expenses and increase awareness of budget assurance). General recommendations for all variables and respondents: group 1 (2,3,4 is closer to each other), who emphasizes that income is related to age and profession. Group 2 (Item 13,1) which emphasizes that financial advice is necessary for both genders. Group 3(Item 9, 8, 12, 7, 14, 10, 5, 6, 11, where variables 9\&11are located a little further from the group), that means that if we do not register and control all transactions costs, we do not have opportunity to create an emergency fund. Distance predictions between variables are close to true distances $Z=.80$, as well as regression confirms the importance of the model $\mathbf{8 0 . 2 \%}$.

\section{Conclusion}

In this paper a significant difference was observed between the observation groups (KO \&EU\&WBC), in both analyzes was emphasized that small economies due to the environment in which they operate, have poorer financial stability and lower welfare compared to large economies. Below we look at some of the key findings:

\subsection{Cluster Analysis}

- Item1, both genders need to increase budget awareness,

- Item2, (KO \& WBC) emphasize that older individuals can make better decisions, while disagrees (EU) arguing that can manage all age groups, but it depends on the desire to increase awareness of budget cycle management,

- Item3, (KO \& WBC) have approximately the same opinion that education and management depend on the profession, but again disagrees (EU), profession helps awareness raising but not all individuals of different professions, can be good budget managers,

- Item4, here the three groups agree that individuals with high incomes does not mean that are good budget managers, they can spend without controlling their budget,

- Item5, (EU) has sufficient decision-making information compared to (WBC), while (KO) has weaker financial information,

- Item6, financial assurance more preferred from countries (EU \& WBC) unlike (KO),

- $\quad$ Item7, the better financial planning for the future is made by the countries of (EU \& WBC) but neither (KO) is not found far,

- Item8, the best savings for retirement was made by the countries of (WBC) unlike (EU\&KO),

- Item9, emergency funds have countries of (EU),

- Item10\&11, the registration of transactions for income and expenses very few is done by countries (KO \& WBC),

- $\quad$ Item12, (EU) countries are interested in investing and saving money unlike (KO),

- Item13, observation groups agree that they need a financial advisor during the budget cycle,

- Item14, the (EU) countries have more financial control,

- According to PCA and the Alpha coefficient, the reliability of the variables is very high (PCA $=.859$ or $86 \%$, Alfa $=.817$ or $81 \%$ ),

- According to the number of cases in each Cluster, the (EU) countries have the highest weight $(\mathrm{EU}=142,000)$,

- $\quad$ Tests (Tukey, Bonferroni, Homogeneity), Anova and CH-Square for observation groups are acceptable at the significance level.000,

- $\quad$ Creating subgroups (the income subgroup is created by $\mathrm{KO}=2.89 \& \mathrm{WBC}=2.94$ unlike $\mathrm{EU}=3.41$ i.e. the income is approximately the same in the sub-group, the financial assurance sub-group is created by EU $=4.06 \&$ $\mathrm{WBC}=3.86$ unlike $\mathrm{KO}=1.92$ i.e. $\mathrm{KO}$ should increase the awareness raising for this item, the financial planning sub-group is created by $\mathrm{EU}=3.43 \& \mathrm{WBC}=3.39$, emergency funds sub-group is created by $\mathrm{EU}=3.16 \& \mathrm{WBC}=$ 2.94, sub-group for revenues and expenditures registration is created by $\mathrm{EU}=4.00 \& \mathrm{WBC}=3.92$, sub-group for investment and savings is created by $\mathrm{EU}=3.81 \& \mathrm{WBC}=3.66$ unlike $\mathrm{KO}=1.92$ i.e. $\mathrm{KO}$ should increase the awareness raising for this item, item for financial advisor has created two sub-groups as $\mathrm{KO}=2.69 \& \mathrm{WBC}=3.15$ 
and $\mathrm{WCB}=3.15 \& \mathrm{EU}=3.26$, the sub-group of practice and budget control is created by $\mathrm{EU}=3.96 \& \mathrm{WBC}=3.54$ unlike $\mathrm{KO}=1.95$ d.m.th. $\mathrm{KO}$ should raise awareness about this article),

- Item $1=48.8 \%$ of cases do not have sufficient information, item $2=39.8$ very few have understood the importance of financial assurance, item $3=81.2 \%$ of cases to some extent plan properly, item $9=55.2 \%$ of the cases to some extent have funds for emergency, item10\&11 $=55.8 \%$ of cases rarely make the expense and income registration, item $12=59.8 \%$ of cases agree that saving and investment is important for better well-being, item $13=$ $64.8 \%$ of cases need financial advice, item $14=61.2 \%$ of cases agree that practice and budget control help financial stability.

\subsection{Multidimensional Scaling (MDS)}

- Observation groups (KO \& EU \& WBC) according matrices of MDS are explained by $77 \%$ and $80 \%$,

- Respondents with code (10-Switzerland, 38-Croatia, 43-Malta, 20-Montenegro, 31-Kosovo, 64-Norway, 54-Austria, 78-England), show a difference from the general trend. SeeGraph.4,

- The distance predictions between the variables are close to the true distances $\mathrm{Z}=.80$ and the regression confirms the importance of the $80.2 \%$ model. SeeGraph5,

- According to the Euclidean distance, the observation groups for all variables should consider the recommendations SeeGraph5 Graph.4,

- As stated earlier in small economies some variables are highly correlated with the environment and other indicators, while other negative variables which depend on the cases if not controlled, can worsen financial stability and well-being in society,

- Relationships between specific results from cluster analysis and MDS analysis indices were statistically significant,

- This study was analyzed only by the variables mentioned.

\section{Acknowledgments}

I thank University "Haxhi Zeka" Peja, for the financial support, as well as all the respondents in all the countries in which the research was conducted.

\section{Conflict of Interest}

The author would like to declare that no conflicts of interest involves in this paper.

\section{References}

A1.Aguiar, M., \& Amador, M. (2011). Growth in the Shadow of Expropriation. The Quarterly Journal of Economics, 651-697. https://doi.org/10.1093/qje/qjr015

A1.Hilgert, M. A., Hogarth, J. M., \& Beverly, S. G. (2003). Household financial management: The connection between knowledge and behavior. Federal Reserve, 309-322. https://doi.org/10.1.1.379.9686

A1.Kruskal, J. B. (1964). Multidimensional scaling by optimizing goodness of fit to a nonmetric hypothesis. Psychometrika, 1-27. https://doi.org/10.1007\%2FBF02289565

Aguiar, M., \& Amador, M. (2011). Growth in the Shadow of Expropriation. The Quarterly Journal of Economics, 651-697. https://doi.org/10.1093/qje/qjr015

Amador, M., Werning, I., \& Angeletos, M. (2006). Commitment vc. flexibility. Technical report. Econometrica, 365-396.

Ankerst, M. et al.. (1999). OPTICS: Ordering Points To Identify the Clustering Structure. ACM Press, pp. 49-60. https://doi.org/10.1145/304181.304187

Bajtelsmit, V., Bernasek, A., \& Jianakoplos, A. (1999). Gender differences in defined contribution pension. Financial Services Review, 1-10. https://doi.org/10.1016/S1057-0810(99)00030-X

Bassett, F., Fleming, J., \& Rodrigues, A. (1998). How workers use 401(k) plans: the participation, contribution, and withdrawal decisions. National Tax Journal, 263-289. Retrieved form https://www.ntanet.org/NTJ/51/2/ntj-v51n02p263-89-how-workers-use-401.pdf

Beck, T., Levine, R., \& Loayza, N. (2000). Finance and the sources of growth. Journal of Financial Economics, 261-300. https://doi.org/10.1016/S0304-405X(00)00072-6 
Beck, T., Demirguc-Kunt, A., \& Levine, R. (2007). Finance, inequality and the poor. Journal of Economic Growth, 27-49. https://doi.org/10.1007/s10887-007-9010-6

Bernheim, D., \& Garrett, M. (1996). The determinants and consequences of financial education in the workplace. National Bureau of Economic Research, 1-54. Retrieved from https://www.nber.org/papers/w5667.pdf

Borg, I., \& Groenen, P. (2005). Modern Multidimensional Scaling: theory and applications (2nd ed.). Springer-Verlag, $\quad$ pp. 2007-2012. $\quad$ Retrieved from https://en.wikipedia.org/wiki/Special:BookSources/978-0-387-94845-4

Brian, K., \& Michael, J. (2012). Revisiting k-means: new algorithms via Bayesian nonparametrics. ICML, 1131-1138. Retrieved from https://en.wikipedia.org/wiki/Special:BookSources/9781450312851

Ferraro, F., \& Su, P. (1999). Financial strain, social relations, and psychological distress among older people: A cross-cultural analysis. The Journals of Gerontology Series B: Psychological Sciences and Social Science, 3-15. https://doi.org/10.1093/geronb/54b.1.s3

Fry, T., Mihajilo, S., Russell, R., \& Brooks, R. (2008). The factors influencing saving in a matched savings program:Goals, knowledge of payment instruments, and other behavior. Journal of Family and Economic, 234-250.

Furnham, A. (1999). The saving and spending habits of young people. Journal of Economic Psychology, 677-697. https://doi.org/10.1016/S0167-4870(99)00030-6

Galperti, S. (2017). A theory of personal budgeting. SSRN, 1-58. https://doi.org/10.2139/ssrn.2964067

Glass, C., \& Kilpatrick, B. (1998). Financial planning for retirement: an imperative for baby boomer women. Educational Gerontology, 595-617. Retrieved from https://psycnet.apa.org/doi/10.1080/0360127980240606.

Gómez, F. (2009). Educacion financiera: retos y lecciones a partir de experiencias representativas en el mundo. Proyecto Capital enbreve, 1-7. $\quad$ Retrieved from https://repositorio.iep.org.pe/bitstream/IEP/1054/1/G\%c3\%b3mez-Franz_Educacion-financiera-retos-lecciones. pdf

Grable, E., \& Lytton, H. (1997). Determinants of retirement savings plan participation: A discriminant. Personal Finances and Worker Productivity, 189-194. Retrieved from https://www.consumerinterests.org/assets/docs/CIA/CIA1998/grablelyttonkratzer.pdf

Hastie, T., Tibshirani, R., \& Friedman, J. (2017). The elements of statistical learning: Data mining, inference and. New York: Springer Science+Business Media, LLC 2009, Corrected at 12th printing

Henkens, K. (1999). Retirement intentions and spousal support: A multi-actor approach. The Journals of Gerontology. Series B: Psychological Sciences and Social Sciences, 63-73. https://doi.org/10.1093/geronb/54B.2.S63

Hershey, A., \& Mowen, C. (2000). Psychological determinants of financial preparedness for retirement. The Gerontologist, 687-697. https://doi.org/10.1093/geront/40.6.687

Hilgert, A., Hogarth, M., \& Beverly, G. (2003). Household financial management: The connection between knowledge and behavior. Federal Reserve Bulletin, 309-322.

Jacobs, L., \& Hershey, D. (2005). Influence of Future Time Perspective, Financial Knowledge, and Financial Risk Tolerance on Retirement Saving Behaviors. Financial Services Review, 331-344.

Jamieson, T., \& Jamieson, P. (2009). Ministry and Money: A Practical Guide for Pastors. United States o America: Westminister John Knock Press.

Joo, S. (2008). Personal Financial Wellness. In J. J. Xiao (Eds.), Handbook of Consumer Finance Research. New York: Springer. https://doi.org/10.1007/978-0-387-75734-6_2

Kahneman, D., \& Tversky, A. (1979). Prospect Theory: An Analysis of Decision under Risk. The Econometric Society, 263-292. https://doi.org/10.2307/1914185

Karlan, D., \& Morduch, J. (2009). Access to Finance. Chapter 2, Handbook of development economics, 1-80. Retrieved from http://citeseerx.ist.psu.edu/viewdoc/download?doi=10.1.1.205.6947\&rep=rep1\&type=pdf

Karlan, D., \& Morduch, J. (2009). Access to Finance. Chapter 2, Handbook of Development Economics, Vol. 5, pp. 1-85. Handbook of Development Economics.

King, G., \& Levine, R. (1993). Finance and growth: Schumpeter might be right. Quarterly Journal of Economics, 


\section{1-50. https://doi.org/10.2307/2118406}

Klapper, L., Laeven, L., \& Rajan, R. (2006). Entry Regulation as a Barrier to Entrepreneurship. Journal of Financial Economics, 591-269. https://doi.org/10.1016/j.jfineco.2005.09.006

Kleinman, G., Anandarajan, A., \& Lawrence, K. (1999). An analysis of the move toward defined contribution pension plans: are the rewards commensurate with the risks?. Journal of Pension Planning and Compliance, 331-334.

Kotlikoff, J., \& Morris, N. (1989). How much care do the aged receive from their children? A bimodal picture ofcontact assistance. D. A. Wise (Ed.). Chicago: IL: University of Chicago.

Kriegel, P., Schubert, E., \& Zimek, A. (2016). The (black) art of runtime evaluation: Are we comparing algorithms or implementations?. Knowledge and Information Systems, 52(2), 341-378. https://doi.org/10.1007/s10115-016-1004-2

Kruskal, J. B., \& Wish, M. (1978). Multidimensional Scaling. Sage University Paper series on Quantitative Application in the Social Sciences, 7-11. https://doi.org/10.4135/9781412985130

Lee, A., Xu, Y., \& Hyde, K. F. (1997). Factors Influencing Investor Choice of Retirement Funds. Financial Literacy and the Limits of Financial Decision-Making, 224-245. https://doi.org/10.1007/978-3-319-30886-9_11

Lewellen, A., Lease, C., \& Schlarbaum, G. (1975). Individual investor risk aversion and investment. The Journal of Finance, 605-620.

Lloyd, S. (1982). Least squares quantization in PCM. IEEE Transactions on Information Theory, 129-136. Retrieved from https://sites.cs.ucsb.edu/ veronika/MAE/kmeans_LLoyd_Least_Squares_Quantization_in_PCM.pdf

Lusardi, A. (2009). Household Savings Behavior: The Role of Financial Literacy, Information and Financial EducationPrograms Programs. In C. Foote, L. Goette, \& S. Meier (Eds.), Policymaking Insights from Behavioral Economics. Federal Reserve Bank of Boston, 109-149. https://doi.org/10.3386/w13824

MacQueen, J. (1967). Some Methods for classification and Analysis of Multivariate Observations. Proceedings of 5th Berkeley Symposium on Mathematical Statistics and Probability, pp. 281-297. Retrieved from https://projecteuclid.org/euclid.bsmsp/1200512992

Mead, A. (1992). Review of the Development of Multidimensional Scaling Methods. Journal of the Royal Statistical Society. Series D (The Statistician), pp. 27-39. Retrieved from https://www.jstor.org/stable/234863

Meier, S., \& Sprenger, C. (2008). Discounting financial literacy: Time preferences and participation in financial education programmes (IZA Discussion Paper No. 3507). Journal of Economic Behaviour and Organization, 159-174. Retrieved from https://www.econstor.eu/handle/10419/35270

Mitchell, S., \& Moore, F. (1998). Can Americans afford to retire? New evidence on retirement savings adequacy. The Journal of Risk Insurance, 371-400. https://doi.org/10.2307/253656

Morissette, L., \& Chartier, L. (2013). The k-means clustering technique: General considerations and implementation in Mathematica. Tutorials in Quantitative Methods for Psychology, 15, 15-24. Retrieved from https://www.researchgate.net/publication/308020680_The_k-means_clustering_technique_General_consideratio ns_and_implementation_in_Mathematica

Nageeb, A. (2011). Learning Self-Control. The Quarterly Journal of Economics, 126(2), 857-893. https://doi.org/10.1093/qje/qjr014

Pham, D. T., Dimov, S. S., \& Nguyen, C. D. (2004). Selection of K in K-means clustering. Manufacturing Engineering Centre, 108. https://doi.org/10.1243/095440605X8298

Scholtz, J. (1992). A direct examination on the dividend clientele hypothesis. Journal of Public Economics, 261-285. https://doi.org/10.1016/0047-2727(92)90069-R

Schreiner, M., \& Sherraden, M. (2007). Can the poor save? Saving and asset building in individual development accounts. New Brunswick: New Brunswick, NJ: Transaction Publishers.

Sherraden, M. (1991). Assets and the Poor: A New American Welfare Policy. CENTER FOR SOCIAL DEVELOPMENT RESEARCH: NY: M. E. Sharpe, Inc.

Sonuga, J., \& Webley, P. (1993). Children's saving: A study in the development of economic behaviour. Journal of Economic 
http://www.sciencedirect.com/science/article/pii/0167-4870(94)90010-8

Soyeon, Sh., Xiao, J., Barber, B., \& Lyons, A. (2009). Pathways to Life Success: A Conceptual Model of Financial Well-Being for Young Adults. Journal of Applied Developmental Psychology, 708-723. https://doi.org/10.1016/j.appdev.2009.02.003

Steinhaus, H. (1957). Sur la division des corps matériels en parties. Bull. Acad. Polon. Sci. (in French), 801-804.

Sterns, L. (1998). The decision to retire or work. In K. W. Schaie, \& C. Schooler (Eds.), Impact of work on older adults. New York: Springer.

Warschauer, T. (2002). The role of universities in the development of the personal financial planning. Financial Services Review, 201-216.

Wiatrowski, W. (1993). Factors affecting retirement income. Monthly Labor Review, 25-35. Retrieved from https://www.researchgate.net/publication/287936634_Factors_affecting_retirement_income

Wickelmaier, F. (2003). An introduction to MDS. Sound Quality Research Unit, Aalborg University, Denmark, pp. 1-26. Retrieved from http://www.mathpsy.uni-tuebingen.de/wickelmaier/pubs/Wickelmaier2003SQRU.pdf

Yuan, Ch., \& Yang, H. (2019). Research on K-Value Selection Method of K-Means. Multidisciplinary Scientific Journal, 226. https://doi.org/10.3390/j2020016

Yuh, Y., \& Olson, P. (1997). Factors affecting the retirement fund levels of self-employed households and wage. Family Economics and Resource Management Biennial, 25-31.

\section{Copyrights}

Copyright for this article is retained by the author(s), with first publication rights granted to the journal.

This is an open-access article distributed under the terms and conditions of the Creative Commons Attribution license (http://creativecommons.org/licenses/by/4.0/). 